\title{
Plant responses to defoliation and resource supplementa- tion in the Pryor Mountains
}

\author{
JACE T. FAHNESTOCK AND JAMES K. DETLING
}

Authors are research scientist, Department of Renewable Resources, University of Wyoming, Laramie, Wyo. 82071-3354; and professor, Department of Biology, Colorado State University, Fort Collins, Colo. 80523-1878. At the time of the research, the senior author was graduate research assistant, Department of Biology, Colorado State University, Fort Collins, Colo.

Abstract

Field studies were conducted in 2 types of grasslands in the Pryor Mountain Wild Horse Range of northern Wyoming and southern Montana to examine plant biomass production and nitrogen responses to the separate and combined effects of graminoid defoliation and increased environmental resource (water or nutrients) supply. Short-term plant responses were monitored over 2 years which differed substantially in growing season precipitation. In the arid, low elevation grassland, total grass biomass was significantly lower in the dry year than the wet year in all treatments. Defoliation of the grasses did not reduce their aboveground biomass production in the wet year, but severely reduced it in the dry year, primarily because of a decrease in tiller density. Mass of remaining individual tillers increased with clipping in the dry year, and nitrogen concentrations of the grasses increased with clipping in both years. Irrigation alone increased total belowground biomass compared to the other treatments, but did not increase the aboveground biomass production of any plant functional group. Clipping plus irrigation resulted in greater total aboveground biomass production and higher nitrogen concentrations of the grasses than control or irrigated treatments. Clipping graminoids in the more mesic montane grassland did not decrease their biomass production in either year, but did increase their nitrogen concentrations and increase the collective aboveground biomass production of the other plant functional groups. Fertilization and fertilization plus clipping significantly increased total aboveground biomass production in both years, and total belowground biomass was greatest in fertilized plots.

Key Words: wild horses, Pryor Mountain Wild Horse Range, primary production, nitrogen, Pseudoroegneria spicata

Many large ungulate herbivores preferentially consume grasses relative to their proportion in the plant community (Schwartz and Ellis 1981, Vinton et al. 1993). This not only changes the relative ability of grasses to acquire resources, but also alters the competitive interactions within the community

Research was funded in part by the Bureau of Land Management and the National Park Service.

Manuscript accepted 26 Aug. 1998.

\section{Resumen}

Se condujeron estudios de campo en 2 tipos de pastizal en el pastizal Pryor Mountain Wild Horse ubicado en el noreste de Wyoming y sureste de Montana. El objetivo de estos estudios fue examinar los efectos individuales y combinados de la defoliación de gramíneas y el incremento de recursos ambientales (agua o nutrientes). Las respuestas de la planta a corto plazo fueron monitoreadas durante 2 años, los cuales difirieron substancialmente en precipitación durante la estación de crecimiento. En la parte árida, pastizal de baja elevación, la producción total de biomasa de gramíneas en todos los tratamientos fue significativamente menor en el año seco que en el año húmedo. En el año húmedo, la defoliación de los zacates no redujó su producción de biomasa aérea, sin embargo, fue severamente reducida en el año seco, debido principalmente a la disminución de la densidad de hijuelos. Durante el año seco, la biomasa remanente de los hijuelos individuales se incrementó con la defoliación. En ambos años, las concentraciones de nitrógeno de los zacates se incrementó con la defoliación. Comparado con los otros tratamientos, la irrigación sola incrementó la biomasa total subterránea, pero no incrementó la producción de biomasa aérea en ninguno de los grupos funcionales de plantas. La defoliación mas irrigación produjó mayores cantidades de biomasa total aérea y concentraciones de nitrógeno que los tratamientos control o de irrigación. La defoliación de gramíneas en el pastizal montano más mésico no disminuyó su producción de biomasa en ninguno de los años de estudio, pero si incrementó su concentración de nitrógeno e incrementó la producción colectiva de biomasa aérea de los otros grupos funcionales de plantas. En ambos años de estudio, la fertilización y la fertilización mas defoliación incrementaron significativamente la producción total de biomasa aérea y la producción total de biomasa subterránea fue superior en las parcelas fertilizadas.

as plant species or functional groups are differentially affected by the direct and indirect effects of selective herbivory. For example, selective grazing of dominant grasses by bison in tallgrass prairie can increase photosynthesis and growth of neighboring ungrazed plants of the same and other species (Fahnestock and Knapp 1993, 1994).

The ability of grasses to compensate for biomass consumed 
by large herbivores is controlled in part by the availability of environmental resources that can readily be acquired by the plants (Chapin and McNaughton 1989). When resources such as water, light, and mineral nutrients are abundant and readily available to plants, increased aboveground productivity of grasses in response to moderate grazing levels is possible (Archer and Tieszen 1980, McNaughton 1985, Seastedt 1985, Hik and Jeffries 1990, Pandey and Singh 1992, Frank and McNaughton 1993). Conversely, when environmental resources are limited, the ability of grasses to replace tissue lost to grazers is reduced. The persistence of plants in grassland ecosystems, therefore, largely depends on the ability of individuals to cope with complex and dynamic interactions between herbivory and limitations of environmental resources.

The environmental resources that most frequently limit the growth of plants and their ability to recover from grazing and other disturbances often differ with the type of grassland being studied. In arid and semi-arid grasslands, water availability most often limits plant growth (Lauenroth 1979, Sala et al. 1988), while in more humid grasslands, or in wet years, light and nutrients, especially nitrogen availability, are more likely to limit plant growth (Knapp and Seastedt 1986, Burke et al. 1991). The response of plants to grazing may also differ between and within species, depending on the nutrient and water stress tolerance of the species present, and on the type of herbivory and its intensity and frequency (Crawley 1983, Wallace et al. 1984, Coughenour et al. 1985a, 1985b, Polley and Detling 1988).

In the Pryor Mountain Wild Horse Range in southern Montana and northern Wyoming, grasses comprise over $70 \%$ of the annual diet of wild horses (Kissell 1996). Little is known, however, about the ability of the grasses in this system to maintain production in response to this potentially substantial grazing pressure, or about the interaction of herbivory with water or nutrient availability in the Pryor Mountains. The principal objective of this research, therefore, was to determine if the dominant grasses in the Pryor Mountain Wild Horse Range could acquire the resources necessary to maintain biomass and nitrogen production in response to selective grass defoliation, or whether there were environmental resource limitations (i.e., water or nutrient limitations) to growth following defoliation. Because the relative competitive ability of other plants may be differentially affected by selective grass herbivory, we also investigated whether selective defoliation of the grasses would result in increased biomass production or nitrogen content of other plant functional groups, particularly forbs. We hypothesized that biomass production and nitrogen concentrations would increase in plants with additional resource supply, and that the potential negative effects of defoliation on grass growth would be ameliorated with increased resource supply.

\section{Materials and Methods}

\section{Site description}

The experiments took place during the summers of 1993, a year with above average growing season precipitation, and 1994, a relatively dry year, in the Pryor Mountain Wild Horse Range, an 18,000 ha refuge located $80 \mathrm{~km}$ south of Billings, Mont. Elevation ranges from $1,190 \mathrm{~m}$ to $2,440 \mathrm{~m}$ in the Pryor Mountains, and annual precipitation varies from about $130 \mathrm{~mm}$ in some lowland areas to over $500 \mathrm{~mm}$ at upper elevations. Our research was carried out in 2 types of grasslands in the Pryor Mountains-a low elevation arid grassland and a more mesic montane grassland-in which plant growth was presumed to be limited, respectively, by water and nutrient availability. To control for grazing, both experiments were established in long-term ( $>20$ years) fenced areas that precluded wild horse use but were similar in botanical composition as those currently grazed by wild horses (Fahnestock 1998).

The first experiment was conducted in an arid lowland community at $1,300 \mathrm{~m}$ above sea level that receives only ca. $230 \mathrm{~mm}$ of precipitation annually. Precipitation data (1982-1994) for this community were obtained from a weather station located about $1 \mathrm{~km}$ south of our study site. Aboveground biomass in this community averages about $128 \mathrm{~g} \mathrm{~m}^{-2}$ (Fahnestock 1998) and is dominated by perennial grasses $(51 \%$ of total plant cover) and forbs (26\% of total plant cover), with lesser quantities of cushion plants, dwarf shrubs and succulents. Pseudoroegneria spicata (Pursh) A.
Löve (bluebunch wheatgrass) is the most abundant plant in these lowland communities, accounting for nearly $50 \%$ of the total herbaceous plant cover and over $90 \%$ of the total grass cover (Fahnestock 1998). Since water presumably limits plant growth in these lowlands, a grass defoliation and water supplementation experiment was carried out in this community.

The second experiment was conducted in a more mesic, montane meadow at $2,400 \mathrm{~m}$ above sea level that receives over $500 \mathrm{~mm}$ of precipitation annually. This site is located approximately $4 \mathrm{~km}$ north-west of the lowland site and precipitation data for this community were obtained from a weather station located about $1 \mathrm{~km}$ north of this site. Vegetation in this community is more abundant than the lowlands, averaging about 177 $\mathrm{g} \mathrm{m}^{-2}$, and consists primarily of grasses and sedges (44\% of total plant cover) and forbs (51\% of total plant cover). Much of the precipitation at this site comes from frequent summer showers, and thus the availability of nutrients, rather than water, presumably limits plant growth here. We carried out a graminoid (grasses and sedges) defoliation and nutrient supplementation experiment at this site.

\section{Experimental design and treatments}

A completely randomized $2 \times 2$ factorial design with 20 replicate plots was utilized for each experiment. Each experiment was established in a representative area of the upland or lowland grassland community at that site, and plots were selected that were relatively uniform in terms of plant cover and species composition to control for differences within and between plots. Each $3.2 \mathrm{~m} \mathrm{X} 3.2 \mathrm{~m}$ plot was subdivided into 4 equal subplots to which a particular treatment was randomly assigned. In the arid lowlands the treatments were grass defoliation (D), irrigation (W), grass defoliation plus irrigation (DW), or untreated control (C). In the more mesic uplands the treatments were graminoid defoliation (D), fertilization (F), graminoid defoliation plus fertilization (DF), or control (C).

Vegetation was sampled in each subplot with $0.25 \mathrm{~m}^{2}$ circular quadrats that were randomly placed in one of 4 possible locations in each subplot. No vegetation sample was collected within $20 \mathrm{~cm}$ 
of the edge of each subplot to avoid edge effects. To simulate recurrent, selective ungulate herbivory, all graminoid biomass in entire defoliated and defoliated plus irrigated or defoliated plus fertilized subplots of each experiment was clipped to a height of $2 \mathrm{~cm}$ once a month in May, June, July, and August of 1993 and 1994, and clipped biomass within the $0.25 \mathrm{~m}^{2}$ quadrats of each treatment was retained. This level of defoliation was equivalent to $60-70 \%$ utilization of the graminoids over the course of the growing season. Additionally, at the lowland site, tillers of $P$. spicata were counted in the 0.25 $\mathrm{m}^{2}$ quadrats of each plot, and individual tiller mass was quantified by weighing 100 tillers from each treatment in August (i.e., 5 randomly selected tillers from each of the 20 plots).

All aboveground biomass in the 0.25 $\mathrm{m}^{2}$ quadrats of each treatment was harvested to ground level in August of both years and oven-dried at $60^{\circ} \mathrm{C}$ for 48 hours. Because all aboveground biomass was harvested to ground level in 1993, alternate $0.25 \mathrm{~m}^{2}$ quadrats within each subplot were sampled in 1994. These alternate plots had received the same treatments except for the ground level harvest in 1993. Biomass and total offtake values for each treatment were sorted by functional group (e.g., live and dead graminoids, forbs, etc.) and weighed. Pooled biomass samples $(n=5)$ of each functional group were ground through an $850 \mu \mathrm{m}$ (20-mesh) screen in a Wiley mill, subsampled, and nitrogen concentrations were determined by cou- pled combustion/reduction and gas chromatography (CHN-1000, LECO Corporation, St. Joseph, Mich.). Aboveground $\mathrm{N}$ yield was calculated by multiplying the $\mathrm{N}$ concentration by the aboveground biomass of each functional group. Root biomass was estimated at the time of final harvest in 1994 by excavating 5 alternate $0.25 \mathrm{~m}^{2}$ quadrats to the depth of $30 \mathrm{~cm}$ for each treatment. Soils were air-dried and roots and rhizomes were separated from soil by sieving.

In the lowland experiment, irrigated subplots were watered with hand-held sprinklers with water obtained from a nearby well. A $26.6 \mathrm{~mm}$ rainfall event was simulated in May, June, and July of each year, approximating a small increase in the number of large rainfall events this lowland area receives during the growing season. A total of $80 \mathrm{~mm}$ of water was added to irrigated plots during each growing season, resulting in a near doubling of the long-term average precipitation received at this site in May -July. Each watering event was applied over a 30-hour span so that there was no significant puddling or runoff, and water appeared to uniformly infiltrate the soil to a depth of at least $25 \mathrm{~cm}$ (pers. obs. based on excavations). This irrigation scheme appeared to increase the availability of soil water to irrigated plants by nearly 3 weeks during the growing season (i.e., irrigated soils were appreciably more moist at $20 \mathrm{~cm}$ than non-irrigated soils for about 1 week following each watering event). In the upland experiment, a moderate level $\left(39 \mathrm{~g} \mathrm{~m}^{-2}\right)$ of slow-release fertilizer (20-10-5 of N-P-
K) was surface-broadcast applied to the appropriate randomly selected subplots once near the beginning (late-May) of the 1993 and 1994 growing seasons. Soils were moist at the time of fertilization and rain fell on the site within 10 days of fertilization. All fertilizer was dissolved into the soil within 4 weeks of application.

\section{Statistical analyses}

In each experiment, total biomass (i.e., May-August clipped biomass plus final August harvest biomass) and nitrogen responses to each treatment were compared using the General Linear Models procedure of the Statistical Analysis System (SAS 1989). Models included the main effects of treatment by functional group and the interaction of treatments. Type III sums-of-squares were used for significance $(\mathrm{P}<0.05)$ testing, and least squares methods were used to examine associations between treatments by functional group. We used ttest procedures to compare biomass and nitrogen responses of each functional group to treatments between years.

\section{Results}

\section{Biomass responses}

Growing season (ca. March-July) precipitation in the lowland site was 202 $\mathrm{mm}$ in 1993, well above the long-term average of $143 \mathrm{~mm}$, while in 1994 it was only $101 \mathrm{~mm}$. Live grass biomass and live plus dead grass biomass were significantly lower in all lowland treat-

Table 1. Mean aboveground biomass $\left(\mathrm{g} \mathrm{m}^{-2}\right) \pm 1 \mathrm{SE}$ of grasses, forbs, and total biomass in control plots and defoliated, irrigated, and defoliated plus irrigated treatments from arid lowland sites $(n=20$ for each functional group $x$ treatment). Values shown are for final harvest in August 1993 and 1994 and include clipped grass biomass from May through August (see text for additional details).

\begin{tabular}{|c|c|c|c|c|}
\hline & Control & Defoliated & Irrigated & $\begin{array}{l}\text { Defoliated and } \\
\text { Irrigated }\end{array}$ \\
\hline & \multicolumn{4}{|c|}{ - - - - - - - - - - - - - - } \\
\hline \multicolumn{5}{|c|}{ 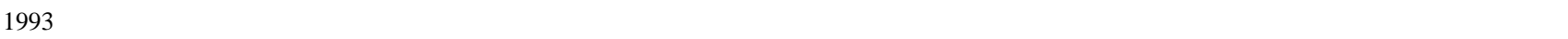 } \\
\hline Grasses & $31.8 \pm 1.0^{\mathrm{a} * \ddagger}$ & $33.3 \pm 1.1^{\mathrm{a} *}$ & $33.4 \pm 1.0^{\mathrm{a} *}$ & $27.5 \pm 0.8^{\mathrm{a} *}$ \\
\hline Live & $10.5 \pm 1.1^{\mathrm{a} *}$ & $13.2 \pm 1.4^{\mathrm{a} *}$ & $12.5 \pm 1.4^{\mathrm{a}_{*}}$ & $11.8 \pm 1.2^{\mathrm{a} *}$ \\
\hline Dead & $21.3 \pm 0.8^{\mathrm{a}}$ & $20.1 \pm 3.3^{\mathrm{a} *}$ & $20.9 \pm 2.8^{\mathrm{a} *}$ & $15.7 \pm 2.0^{\mathrm{a}}$ \\
\hline Forbs & $25.8 \pm 2.9^{\mathrm{a}}$ & $33.3 \pm 3.4^{\mathrm{a}}$ & $30.0 \pm 2.6^{\mathrm{a}}$ & $27.2 \pm 3.2^{\mathrm{a}}$ \\
\hline Total aboveground biomass & $137.2 \pm 4.5^{\mathrm{a}}$ & $135.6 \pm 4.7^{\mathrm{a}}$ & $135.4 \pm 4.5^{\mathrm{a}}$ & $126.8 \pm 5.2^{\mathrm{aa}}$ \\
\hline \multicolumn{5}{|l|}{1994} \\
\hline Grasses & $22.7 \pm 1.0^{\mathrm{a}_{*}}$ & $8.6 \pm 0.4 b^{*}$ & $19.0 \pm 0.6^{\mathrm{a}_{*}}$ & $14.2 \pm 0.7^{\mathrm{ab} *}$ \\
\hline Live & $6.2 \pm 1.1^{\mathrm{a} *}$ & $3.1 \pm 0.3 b^{*}$ & $5.6 \pm 0.7^{\mathrm{ab} *}$ & $4.4 \pm 0.6^{\mathrm{ab} *}$ \\
\hline Dead & $16.6 \pm 3.0^{\mathrm{a}}$ & $5.5 \pm 1.2 b^{*}$ & $13.4 \pm 1.9^{\mathrm{a}}$ & $9.8 \pm 2.3^{\mathrm{ab}}$ \\
\hline Forbs & $21.0 \pm 2.8^{\mathrm{a}}$ & $24.4 \pm 3.7^{\mathrm{a}}$ & $30.3 \pm 4.5^{\mathrm{a}}$ & $29.8 \pm 3.4^{\mathrm{a}}$ \\
\hline Total aboveground biomass & $119.2 \pm 7.2^{\mathrm{a}}$ & $123.3 \pm 12.2^{\mathrm{a}}$ & $134.6 \pm 10.2^{\mathrm{ab}}$ & $149.5 \pm 8.5^{\mathrm{b}}$ \\
\hline
\end{tabular}

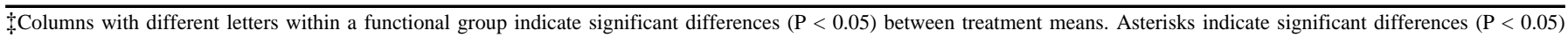
between 1993 and 1994 values. 

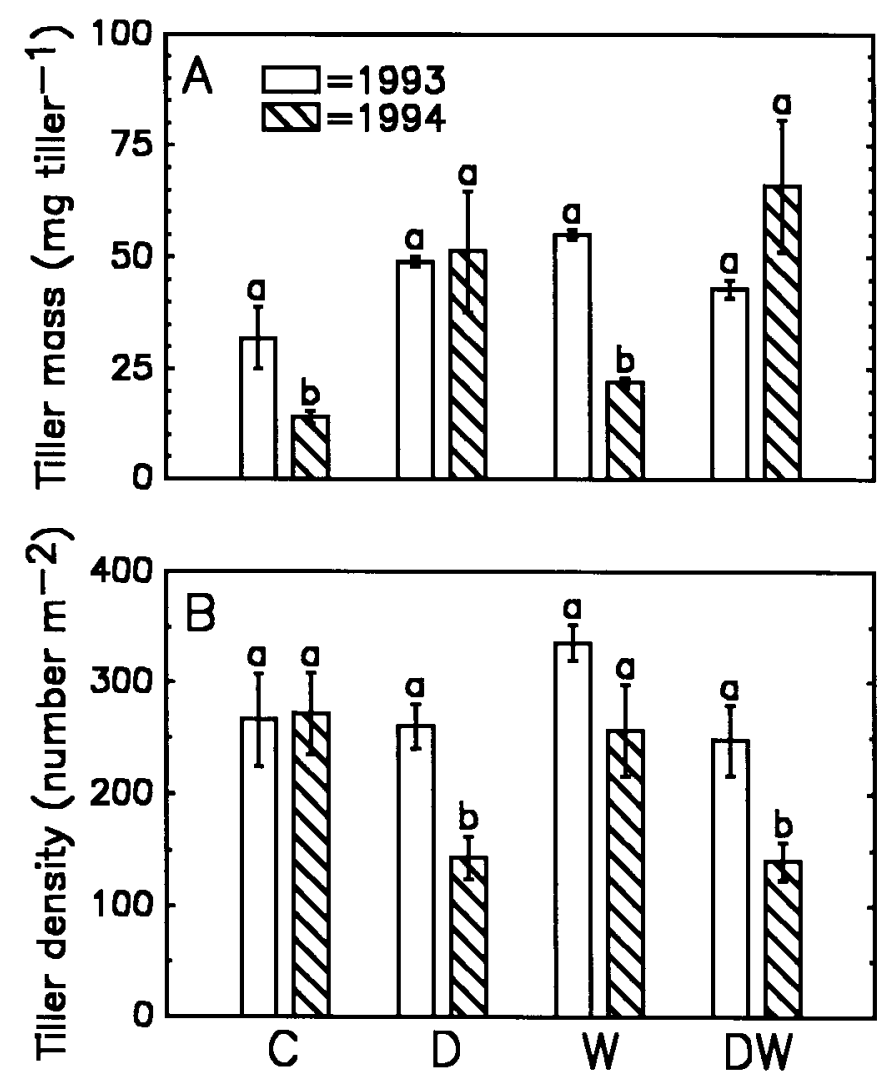

Fig. 1. (a) Individual grass tiller mass $\left(\mathrm{mg} \mathrm{tiller}^{-1}\right)$ and (b) tiller density $\left(\right.$ no. $\left.^{-2}\right)$ in 1993 , a wet year, and 1994, a dry year, in the lowland experimental site of the PMWHR. Measurements were made on Pseudoroegneria spicata, the dominant grass in these lowlands. Different letters above bars indicate significant $(P<0.05)$ differences in means between treatments and years. Treatments are control (C), grasses defoliated (D), irrigated (W), and defoliated plus irrigated (DW).

ments in 1994 than 1993 (Table 1). However, forb and total aboveground biomass were not significantly lower in 1994 than 1993 in any treatment. In the lowland experiment, there was not a significant effect of any of the treatments (defoliated, irrigated, or defoliated plus irrigated) on biomass production of any plant functional group in 1993, the wet year (Table 1). This was not the case, however, in 1994, where grass biomass production was much lower in defoliated plots $\left(9 \mathrm{~g} \mathrm{~m}^{-2}\right)$ than in control plots (23 $\mathrm{g} \mathrm{m}^{-2}$; Table 1$)$.

Much of the lower live grass biomass production in 1994, the dry year, was the result of lower mass of individual live grass tillers. In control plots, mass was $32 \mathrm{mg} \mathrm{tiller}^{-1}$ in 1993 but only 14 mg tiller ${ }^{-1}$ in 1994 (Fig. 1a). A similar reduction in tiller mass was seen in grasses that were irrigated. In contrast, individual mass of grass tillers that were defoliated (both defoliated and defoliated plus irrigated treatments) were not reduced, but defoliation did reduce tiller density in the dry year (Fig. 1b). Grass tiller density in control plots was about 270 tillers $\mathrm{m}^{-2}$ in both years. In defoliated treatments, density averaged 260 tillers $\mathrm{m}^{-2}$ in 1993 , but only 140 tillers $\mathrm{m}^{-2}$ in 1994 (Fig. 1b).

Irrigation did not increase aboveground biomass production of any plant functional group in either year (Table 1). Total belowground biomass, however, was greatest in irrigated plots by the end of the experiment (Fig. 2a). Total belowground biomass in irrigated plots was $158 \mathrm{~g} \mathrm{~m}^{-2}$, while that in control, defoliated, and defoliated plus irrigated plots averaged $98 \mathrm{~g} \mathrm{~m}^{-2}$ (Fig. 2a). Irrigation apparently also enabled the grasses to compensate, at least in part, for tissue lost to clipping during the dry year; that is, in the dry year defoliation alone reduced live and dead aboveground grass biomass, but biomass of grasses in defoliated plus irrigated plots was not different from that of control plots (Table 1). The combined effects of defoliation and irrigation did not significantly alter aboveground biomass of any individual plant functional groups, but did result in greater total aboveground biomass production than control and defoliated treatments by the end of the experiment in 1994.

In the upland study site, growing season (ca. April-August) precipitation was also lower in $1994(193 \mathrm{~mm})$ than in 1993 (399 mm). Nevertheless, we found no interannual differences in aboveground biomass production of any plant functional group in control plots (Table
Table 2. Mean aboveground biomass $\left(\mathrm{g} \mathrm{m}^{-2}\right) \pm 1 \mathrm{SE}$ of grasses, forbs, and total biomass in control plots and defoliated, fertilized, and defoliated plus fertilized treatments from montane sites $(n=$ 20 for each functional group $x$ treatment). Values shown are for final harvest in August 1993 and 1994 and include clipped graminoid biomass from May through August (see text for additional details).

\begin{tabular}{|c|c|c|c|c|}
\hline & Control & Defoliated & Fertilized & $\begin{array}{l}\text { Defoliated and } \\
\text { Fertilized }\end{array}$ \\
\hline & \multicolumn{4}{|c|}{$-\ldots$} \\
\hline \multicolumn{5}{|c|}{ 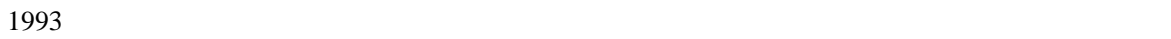 } \\
\hline Graminoids & $48.5 \pm 6.4^{\mathrm{a}} \ddagger$ & $54.2 \pm 5.0^{\mathrm{a}}$ & $61.7 \pm 7.2^{\mathrm{a}_{*}}$ & $65.4 \pm 6.6^{\mathrm{a}}$ \\
\hline Live & $25.4 \pm 2.9^{\mathrm{a}}$ & $30.9 \pm 2.6^{\mathrm{a}}$ & $42.0 \pm 4.8^{\mathrm{b}_{*}}$ & $45.2 \pm 4.6^{\mathrm{b}}$ \\
\hline Dead & $23.0 \pm 4.2^{\mathrm{a}}$ & $23.2 \pm 2.7^{\mathrm{a}}$ & $19.7 \pm 4.1^{\mathrm{a} *}$ & $20.1 \pm 3.1^{\mathrm{a}}$ \\
\hline Forbs & $82.0 \pm 10.7^{\mathrm{a}}$ & $84.0 \pm 7.0^{\mathrm{a}}$ & $93.6 \pm 11.3^{\mathrm{a} *}$ & $110.3 \pm 17.9^{\mathrm{a}}$ \\
\hline Total aboveground biomass & $175.6 \pm 11.1^{\mathrm{a}}$ & $193.1 \pm 13.1^{\mathrm{ab}}$ & $234.9 \pm 17.4^{\mathrm{bc} *}$ & $234.5 \pm 15.2^{\mathrm{bc} *}$ \\
\hline \multicolumn{5}{|l|}{1994} \\
\hline Graminoids & $49.7 \pm 6.0^{\mathrm{a}}$ & $41.2 \pm 6.2^{\mathrm{a}}$ & $105.6 \pm 8.1^{\mathrm{b} *}$ & $59.6 \pm 6.5^{\mathrm{a}}$ \\
\hline Live & $27.8 \pm 3.1^{\mathrm{ab}}$ & $21.8 \pm 2.4^{\mathrm{a}}$ & $57.5 \pm 4.9^{c_{*}}$ & $36.1 \pm 4.4^{b}$ \\
\hline Dead & $21.9 \pm 3.2^{\mathrm{a}}$ & $19.4 \pm 3.5^{\mathrm{a}}$ & $48.1 \pm 6.3^{\mathrm{b} *}$ & $23.5 \pm 2.5^{\mathrm{a}}$ \\
\hline Forbs & $90.1 \pm 12.0^{\mathrm{a}}$ & $101.2 \pm 12.8^{\mathrm{ab}}$ & $146.8 \pm 16.8^{\mathrm{c}_{*}}$ & $137.4 \pm 13.7^{\mathrm{bc}}$ \\
\hline Total aboveground biomass & $177.7 \pm 18.2^{\mathrm{a}}$ & $211.7 \pm 22.5^{\mathrm{b}}$ & $338.3 \pm 19.8^{\mathrm{c}_{*}}$ & $282.8 \pm 17.4^{\mathrm{c} *}$ \\
\hline
\end{tabular}

Tolumns with different letters within a functional group indicate significant differences $(\mathrm{P}<0.05)$ between treatment means. Asterisks indicate significant differences $(\mathrm{P}<0.05)$ between 1993 and 1994 values. 
2). Selective defoliation of the graminoids also did not significantly reduce their biomass production in either year. However, defoliated plots did have greater total aboveground biomass than control plots by the end of the experiment (Table 2 ).

Fertilization increased live graminoid biomass in both years, and total live and dead graminoid biomass was highest in fertilized plots by the end of the experiment in 1994. At that time, live $\left(58 \mathrm{~g} \mathrm{~m}^{-2}\right)$ and dead $\left(48 \mathrm{~g} \mathrm{~m}^{-2}\right)$ graminoid biomass in fertilized plots was more than twice that in control or defoliated plots (Table 2). Aboveground biomass production of all plant functional groups was higher in fertilized plots in 1994 than in 1993 (Table 2). Total belowground biomass in fertilized plots $\left(620 \mathrm{~g} \mathrm{~m}^{-2}\right)$ was greater than that of control $\left(391 \mathrm{~g} \mathrm{~m}^{-2}\right)$ or defoliated $\left(306 \mathrm{~g} \mathrm{~m}^{-2}\right)$ plots by the end of the experiment, but was not significantly different from defoliated plus fertilized plots (453 $\mathrm{g} \mathrm{m}^{-2}$ Fig. 2b). The defoliation plus fertilization treatment increased live graminoid biomass in 1993 compared to control plots, but total grass biomass was not significantly changed by this treatment (Table 2). Additionally, total aboveground biomass was significantly higher in defoliated plus fertilized plots than in control plots in both years.

\section{Nitrogen responses}

In the arid lowland grassland, $\mathrm{N}$ concentrations of both live and dead grass in defoliated and defoliated plus irrigat-

Table 3. Nitrogen concentrations $(\%)$ of live and dead grass and forbs in 1993, a wet year, and 1994, a dry year, from the lowland experimental site $(n=5$ for each functional group $x$ treatment).

\begin{tabular}{|c|c|c|c|c|}
\hline & Control & Defoliated & Irrigated & $\begin{array}{l}\text { Defoliated and } \\
\text { Irrigated }\end{array}$ \\
\hline & \multicolumn{4}{|c|}{ 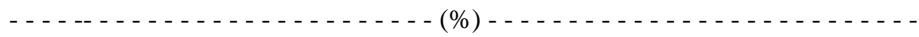 } \\
\hline \multicolumn{5}{|l|}{1993} \\
\hline Live grass & $0.81 \pm 0.01^{\mathrm{a} * \ddagger}$ & $1.26 \pm 0.05^{\mathrm{b} *}$ & $0.85 \pm 0.04^{\mathrm{a} *}$ & $1.25 \pm 0.03^{b_{*}}$ \\
\hline Dead grass & $0.45 \pm 0.01^{\mathrm{a} *}$ & $0.62 \pm 0.02^{\mathrm{b}} *$ & $0.46 \pm 0.02^{\mathrm{a} *}$ & $0.61 \pm 0.03^{\mathrm{b}_{*}}$ \\
\hline Forbs & $0.78 \pm 0.03^{\mathrm{a}}$ & $0.84 \pm 0.03^{\mathrm{a}}$ & $0.82 \pm 0.02^{\mathrm{a}}$ & $0.95 \pm 0.04^{\mathrm{a}}$ \\
\hline \multicolumn{5}{|l|}{1994} \\
\hline Live grass & $0.66 \pm 0.02^{\mathrm{a} *}$ & $0.80 \pm 0.02^{\mathrm{b}} *$ & $0.62 \pm 0.02^{\mathrm{a} *}$ & $0.78 \pm 0.02^{\mathrm{b} *}$ \\
\hline Dead grass & $0.53 \pm 0.03^{\mathrm{a} *}$ & $0.76 \pm 0.01^{b} *$ & $0.55 \pm 0.04^{\mathrm{a}} *$ & $0.75 \pm 0.01^{b_{*}}$ \\
\hline Forbs & $0.80 \pm 0.03^{\mathrm{a}}$ & $0.95 \pm 0.19^{\mathrm{a}}$ & $0.79 \pm 0.04^{\mathrm{a}}$ & $0.81 \pm 0.03^{\mathrm{a}}$ \\
\hline
\end{tabular}

$\$$ Columns with different letters within a functional group indicate significant differences $(\mathrm{P}<0.05)$ between treatment means. Asterisks indicate significant differences $(\mathrm{P}<0.05)$ between 1993 and 1994 values.

ed plots were higher in both years than those in either control or irrigated plots (Table 3). The $\mathrm{N}$ concentration of live grasses was significantly lower in all treatments in 1994, the dry year, than in 1993, the wet year (Table 3). In contrast, the $\mathrm{N}$ concentration of dead grasses was higher in all treatments in 1994 than in 1993. The N concentrations of the forbs were not significantly affected by selective grass defoliation in either year.

In the more mesic montane grassland, all treatments (defoliated, fertilized, and defoliated plus fertilized) resulted in increased $\mathrm{N}$ concentrations in the live graminoids, and defoliated and defoliated plus fertilized increased the $\mathrm{N}$ concentration of the dead graminoids, in both years (Table 4). As at the lowland site, $\mathrm{N}$ concentrations of live graminoids

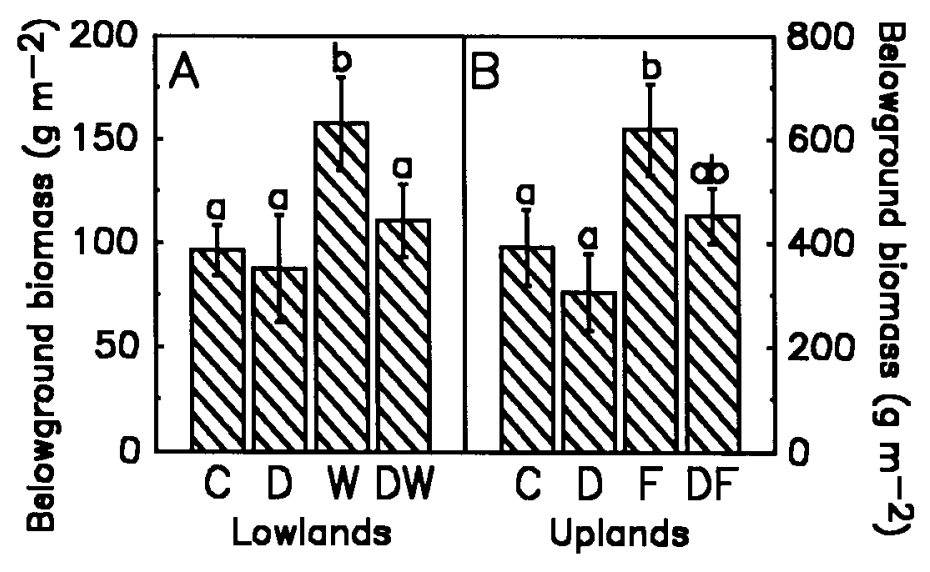

Fig. 2. Total belowground biomass $\left(\mathrm{g} \mathrm{m}^{-2}\right)$ in the (a) lowland and (b) upland experimental sites at the conclusion of the experiment in August, 1994. Columns headed by different letters indicate significant $(P<0.05)$ differences between treatments. Treatments are control (C), graminoids defoliated (D), irrigation (W) or fertilization (F), and graminoids defoliated plus irrigation (DW) or graminoids defoliated plus fertilization (DF). Note different scales for the 2 sites. were higher in all treatments in 1993 than in 1994, and $\mathrm{N}$ concentrations of the forbs were not affected by any treatment in either year.

Total aboveground nitrogen yield ( $\mathrm{g} \mathrm{N}$ $\mathrm{m}^{-2}$ ) of the lowland and upland graminoids was increased by defoliation only in 1993, the wetter year (Fig. 3). Aboveground $\mathrm{N}$ yield of all lowland plants combined was increased in the defoliated plus irrigated treatment by the end of the experiment in 1994, and in the upland experiment, fertilization and defoliation and fertilization increased the aboveground $\mathrm{N}$ yield of the graminoids and of all plants combined in both years.

\section{Discussion and Conclusions}

In the wet year, 1993, selective defoliation of the lowland grasses, primarily $P$. spicata, had no effect on their aboveground biomass production; that is, the grasses fully compensated for the shoot biomass removed. In the dry year, however, defoliation in the absence of water supplementation severely reduced grass biomass production. Irrigation in that year enabled $P$. spicata to compensate for shoot biomass lost to clipping. Consistent with our hypothesis, these data suggest that in the arid lowlands of the Pryor Mountain Wild Horse Range, regrowth following grazing is closely linked to water availability.

Similar reductions in grass biomass production in response to the simultaneous pressures of clipping and water stress have also been found in other studies (e.g., Toft et al. 1987, Georgiadis et al. 1989, Simoes and Baruch 1991, Busso and Richards 


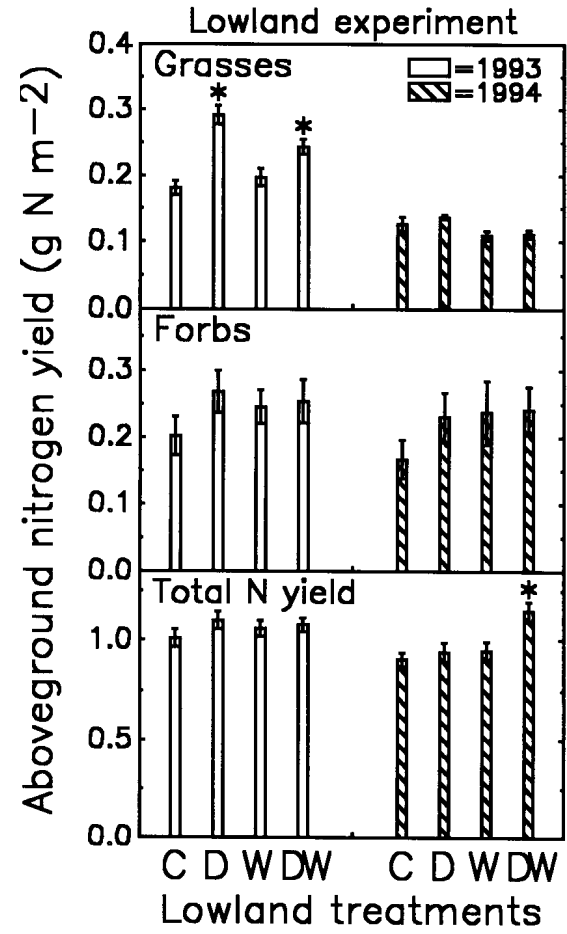

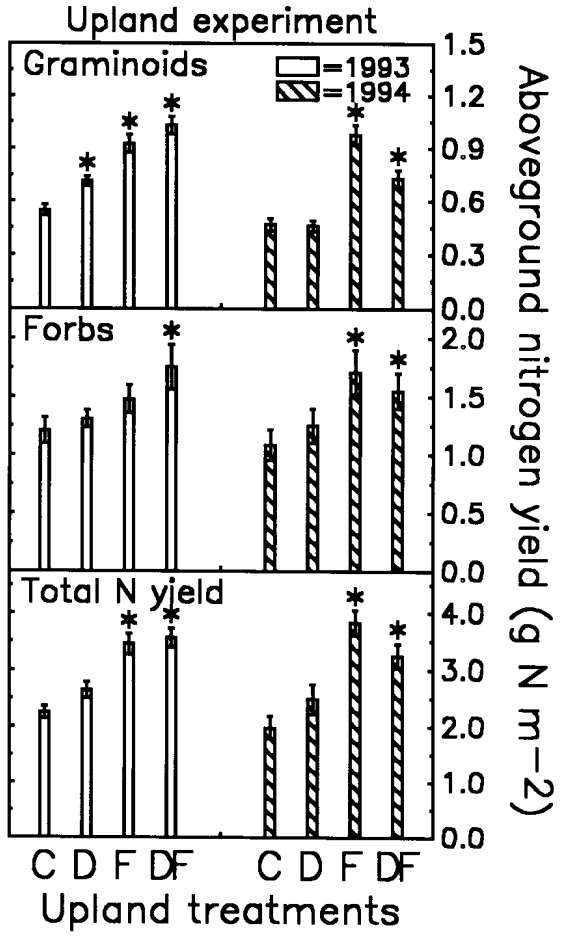

Fig. 3. Aboveground nitrogen yield $\left(\mathrm{g} \mathrm{N} \mathrm{m}^{-2} ; \mathbf{n}=5\right.$ for each vertical bar) for graminoids, forbs, and total $N$ yield in the lowland and upland experiments in August, 1993 and August, 1994. Treatments as in Fig. 2. Asterisks denote significantly higher N yields (calculated as $\mathbf{N}$ concentration multiplied by aboveground biomass) in treatment than control. Note different scales for each graph.

1995). This response, however, is in contrast to the prediction of Hilbert et al. (1981) that plants which are stressed in some way, and consequently growing slowly compared to their potential rates, are most likely to increase production following grazing. The response of the lowland grasses in the Pryor Mountains was also not consistent with those of McNaughton et al. (1983) and Coughenour et al. (1985 a, 1985b, 1990); in their studies, the effects of water stress and defoliation were found to often act singly and 1 factor could reduce or ameliorate the negative effect of the other. In our study, additional water supply ameliorated the negative effects of defoliation in the dry year. In the semiarid shortgrass steppe, Milchunas et al. (1994) have found that long-term primary production across 50 years of cattle grazing treatments was most sensitive to precipitation and least sensitive to grazing intensity.

In the dry year, decreased live grass biomass in the lowland control plots was the result of lower individual tiller mass, not tiller density. Busso and treatment). either the dry or wet year. Why P. spicata failed to increase its aboveground biomass production in response to artificially increased water supply is not known. Although bare ground evaporation was undoubtedly high, soil excavations showed that soil moisture was appreciably higher in irrigated compared to non-irrigated plots for at least 1 week following each watering event. It is possible that the grasses in these arid lowlands are rather insensitive to large pulses of increased water availability, such as those simulated in this study, and that frequent, smaller rainfall events may be more important to their growth (e.g., Sala and Lauenroth 1982, but see Weaver 1985). Additionally, the overall environment in these lowlands was still arid which may have negated the effects of our irrigation treatment. Nevertheless, total root biomass was significantly higher in the lowland irrigated plots than in the other treatments by the end of the experiment, indicating that plant growth responses to our levels of irrigation may have been belowground only.

In the lowland site, the reduction in grass biomass with clipping that was measured in the dry year was the result of a decrease in grass tiller density and not individual tiller mass, which was much higher in clipped than control plots that year. Bluebunch wheatgrass, the dominant grass in these lowlands, has been shown to be a decreaser under increasing grazing pressure (Williams 1963). A decrease in tiller number resulting from grazing has frequently been reported (Branson 1956, Ellison 1960, Caldwell et al. 1981, Carman and Briske 1985, Polley and Detling 1989), although an increase in tiller production (Richards et al. 1988, Zhang and Romo 1995) and

Table 4. Nitrogen concentrations $(\%)$ of live and dead graminoids and forbs in 1993, a wet year, and 1994, a dry year, from the montane experimental site $(n=5$ for each functional group $x$

\begin{tabular}{|c|c|c|c|c|}
\hline & Control & Defoliated & Fertilized & $\begin{array}{l}\text { Defoliated and } \\
\text { Fertilized }\end{array}$ \\
\hline & \multicolumn{4}{|c|}{ 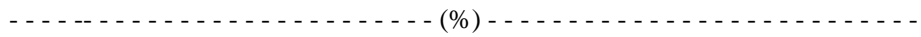 } \\
\hline \multicolumn{5}{|c|}{ (2) } \\
\hline Live graminoids & $1.37 \pm 0.04^{\mathrm{a} *}$ & $1.50 \pm 0.02^{b_{*}}$ & $1.72 \pm 0.02^{c_{*}}$ & $1.76 \pm 0.06^{\mathrm{c} *}$ \\
\hline Dead graminoids & $0.90 \pm 0.03^{\mathrm{a}} *$ & $1.08 \pm 0.05^{\mathrm{b}}$ & $1.04 \pm 0.05^{\mathrm{ab} *}$ & $1.17 \pm 0.05^{\mathrm{b}}$ \\
\hline Forbs & $1.47 \pm 0.05^{\mathrm{a}}$ & $1.56 \pm 0.03^{\mathrm{a}}$ & $1.58 \pm 0.07^{\mathrm{a}}$ & $1.59 \pm 0.06^{\mathrm{a}}$ \\
\hline \multicolumn{5}{|l|}{1994} \\
\hline Live graminoids & $1.13 \pm 0.02^{\mathrm{a} *}+$ & $1.27 \pm 0.05^{\mathrm{bc}_{*}}$ & $1.24 \pm 0.02^{\mathrm{b} *}$ & $1.37 \pm 0.06^{\mathrm{c}_{*}}$ \\
\hline Dead graminoids & $0.70 \pm 0.07^{\mathrm{a} *}$ & $0.94 \pm 0.08^{\mathrm{b}}$ & $0.55 \pm 0.01^{\mathrm{a} *}$ & $1.00 \pm 0.10^{\mathrm{b}}$ \\
\hline Forbs & $1.27 \pm 0.03^{\mathrm{a}}$ & $1.33 \pm 0.08^{\mathrm{a}}$ & $1.35 \pm 0.05^{\mathrm{a}}$ & $1.25 \pm 0.06^{\mathrm{a}}$ \\
\hline
\end{tabular}

\$Columns with different letters within a functional group indicate significant differences $(\mathrm{P}<0.05)$ between treatment means. Asterisks indicate significant differences $(\mathrm{P}<0.05)$ between 1993 and 1994 values. 
increased regrowth of surviving tillers (Branson 1956, Caldwell et al. 1981, McNaughton et al. 1983, Carman and Briske 1985), has also been observed. In this system there appears to be an inverse relationship between tiller size and density, as is generally the case (Risser 1969, Gorham 1979, Christiansen and Svejcar 1988). The simultaneous pressures of clipping and water stress reduced tiller density of $P$. spicata, but increased the mass of the surviving tillers relative to those of unclipped plants. Additions of water to clipped plots in the dry year did not prevent a reduction in tiller density following clipping, providing further evidence to suggest that $P$. spicata is not very responsive to the large, infrequent rainfall events simulated in this shortterm study.

In the upland defoliation-fertilization experiment, the decrease in growing season precipitation in 1994 compared to 1993 did not result in a decrease in aboveground biomass production of any plant functional group, suggesting that water did not limit plant growth at this site during the study. This was not true at all upland sites in the Pryor Mountain Wild Horse Range, however, since decreases in plant cover and biomass were measured at some sites in the dry year (Peterson et al. 1997, Fahnestock 1998). At this site, our finding that defoliation did not reduce live or total graminoid biomass production in either year indicates that the graminoids are apparently able to compensate for biomass lost to grazers without additional resource supply.

Fertilization increased the growth of most plant functional groups such that total above- and belowground biomass production were higher in fertilized only plots than unfertilized plots by the end of the experiment. In individual plants, nutrient limitation is recognized by an increase in growth in response to an addition of the limiting nutrient. The analogous response at the community level is an increase in total community production in response to fertilization (Chapin et al. 1986). In this experiment only, the upland graminoids increased their aboveground biomass production in response to fertilization in the first year, but by the second year all plant functional groups had increased biomass production. These results suggest that species or functional groups differed in their ability to respond to increased nutrient supply or that nutrient limitations were not the same for all plants (Chapin 1980, Jaramillo and Detling 1992). Fertilization also resulted in defoliated graminoids producing more live, but not dead, biomass in 1993, than unclipped, unfertilized plants. Therefore, the effect of increased nutrient supply on defoliated graminoids in the uplands may be to decrease their rate of senescence, and to increase their belowground biomass production (see above).

Our results suggest that the dominant graminoids in the Pryor Mountains are able to withstand fairly heavy levels of defoliation through compensatory growth. In the uplands, the graminoids are able to compensate for tissue lost to grazers without additional resource supply. In the lowlands, however, their ability to fully regrow following grazing is only possible when water availability is not too low. Increased water availability in the lowlands of the Pryor Mountains will most likely stimulate belowground growth in these plant communities, and will increase the nitrogen concentrations of all plants except perhaps the forbs.

In both the lowland and upland communities, selective graminoid defoliation increased the $\mathrm{N}$ concentrations of graminoids in both years, and increased total aboveground $\mathrm{N}$ yield of graminoids in the wet year. This may have resulted from increased $\mathrm{N}$ uptake by defoliated grasses, increased allocation of $\mathrm{N}$ to aboveground plant tissue, or both. Nitrogen uptake, $\mathrm{N}$ concentration, and physiological activity are often higher in plants that have been grazed or otherwise defoliated than in plants from ungrazed areas (e.g., Jameson 1963, Detling et al. 1979, McNaughton 1979, Coppock et al. 1983, McNaughton et al. 1983, Ruess et al. 1983, Detling and Painter 1983, Polley and Detling 1988, Jaramillo and Detling 1988). Increased $\mathrm{N}$ concentrations in grazed graminoids results in higher quality forage available to herbivores. This may have important consequences for subsequent food preference by herbivores in the Pryor Mountain Wild Horse Range. In addition, the higher $\mathrm{N}$-yield of defoliated graminoids suggests that herbivores may, via their grazing activities, increase not only the quality of their forage but also the quantity of crude protein subsequently available to them when they regraze the same patch. Defoliation of the graminoids did not change the aboveground biomass production or nitrogen concentrations of the other plant functional groups in the Pryor Mountains, indicating that the relative competitive abilities of plants in the upland and lowland communities are not greatly, or at least rapidly, altered by selective graminoid defoliation.

\section{Literature Cited}

Archer, S. and L.L. Tieszen. 1990. Growth and physiological responses of tundra plants to defoliation. Arct. Alp. Res. 12:531-552.

Branson, F.A. 1956. Quantitative effects of clipping treatments on five range grasses. J. Range Manage. 9:86-88.

Burke, I.C., T.G.F. Kittel, W.K. Lauenroth, P. Snook, C.M. Yonker, and W.J. Parton. 1991. Regional analysis of the central Great Plains. BioSci. 41:685-692.

Busso, C.A. and J.H. Richards. 1995. Drought and clipping effects on tiller demography and growth of two tussock grasses in Utah. J. Arid Environ. 29:239-251.

Caldwell, M.M., J.H. Richards, D.A. Johnson, R.S. Nowak, and R.S. Dzurec. 1981. Coping with herbivory: photosynthetic capacity and resource allocation in two semiarid Agropyron bunchgrasses. Oecologia 50:14-24.

Carman, J.G. and D.D. Briske. 1985. Morphologic and allozymic variation between long-term grazed and non-grazed populations of the bunchgrass Schizachyrium scoparium var. frequens. Oecologia 66:332-337.

Chapin, F.S., III. 1980. The mineral nutrition of wild plants. Annu. Rev. Ecol. Syst. 11:233-260.

Chapin, F.S., III and S.J. McNaughton. 1989. Lack of compensatory growth under phosphorus deficiency in grazing-adapted grasses from the Serengeti plains. Oecologia 79:551-557.

Chapin, F.S., III, P.M. Vitousek, and K. Van Cleve. 1986. The nature of nutrient limitation in plant communities. Amer. Nat. 127:48-58.

Christiansen, S. and T. Svejcar. 1988. Grazing effects on shoot and root dynamics and above- and below-ground nonstructural carbohydrates in Caucasian bluestem. Grass Forage Sci. 43:111-119.

Coppock, D.L., J.K. Detling, J.E. Ellis, and M.I. Dyer. 1983. Plant-herbivore interactions in a North American mixedgrass prairie. I. Effects of black-tailed prairie dogs on intraseasonal aboveground plant biomass and nutrient dynamics and plant species diversity. Oecologia 56:1-9.

Coughenour, M.B., S.J. McNaughton, and L.L. Wallace. 1985a. Responses of an African tall-grass (Hyparrhenia filipendula staph.) to defoliation and limitation of water and nitrogen. Oecologia 68:80-86. 
Coughenour, M.B., S.J. McNaughton, and L.L. Wallace. 1985b. Responses of an African graminoid (Themeda triandra Forsk.) to frequent defoliation, nitrogen, and water: a limit of adaptation to herbivory. Oecologia 68:105-110.

Coughenour, M.B., J.K. Detling, I.E. Bamberg, and M.M. Mugambi. 1990. Production and nitrogen responses of the African dwarf shrub Indigofera spinosa to defoliation and water limitation. Oecologia 83:546-552.

Crawley, M.J. 1983. Herbivory: the dynamics of animal-plant interactions. University of California Press, Berkeley, Calif.

Detling, J.K. and E.L. Painter. 1983. Defoliation responses of western wheatgrass populations with diverse histories of prairie dog grazing. Oecologia 57:65-71.

Detling, J.K., M.I. Dyer, and D.T. Winn. 1979. Net photosynthesis, root respiration, and regrowth of Bouteloua gracilis following simulated grazing. Oecologia 41:127134.

Ellison, L. 1960. Influence of grazing on plant succession of rangelands. Bot. Rev. 26:1-78

Fahnestock, J.T. 1998. Vegetation responses to herbivory and resource supplementation in the Pryor Mountain Wild Horse Range. Ph.D. Diss. Colorado State Univ., Fort Collins, Colo.

Fahnestock, J.T. and A.K. Knapp. 1993. Water relations and growth of tallgrass prairie forbs in response to selective grass herbivory by bison. Int. J. Plant Sci. 154:432-440.

Fahnestock, J.T. and A.K. Knapp. 1994. Plant responses to selective grazing by bison: interactions between light, herbivory and water stress. Vegetatio 115:123-131

Frank, D.A. and S.J. McNaughton. 1993. Evidence for the promotion of aboveground grassland production by native large herbivores in Yellowstone National Park. Oecologia 96:157-161.

Georgiadis, N.J., R.W. Ruess, S.J. McNaughton, and D. Western. 1989. Ecological conditions that determine when grazing stimulates grass production. Oecologia 81:316-322.

Gorham, E. 1979. Shoot height, weight, and standing crop in relation to density of monospecific stands. Nature 279:148-150.

Hik, D.S. and R.L. Jeffries. 1990. Increases in the net above-ground primary production of salt-marsh forage grass: a test of the predictions of the herbivore-optimization model. J. Ecol. 78:180-195.

Hilbert, D.W., D.M. Swift, J.K. Detling, and M.I. Dyer. 1981. Relative growth rates and the grazing optimization hypothesis. Oecologia 51:14-18.

Jameson, D.A. 1963. Responses of individual plants to harvesting. Bot. Rev. 29:532-594.
Jaramillo, V.J. and J.K. Detling. 1988. Grazing history, defoliation, and competition: effects on shortgrass production and nitrogen accumulation. Ecol. 69:1599-1608.

Jaramillo, V.J. and J.K. Detling. 1992. Small scale heterogeneity in a semi-arid North American grassland. I. Tillering, N uptake and retranslocation in simulated urine patches. J. Appl. Ecol. 29:1-8.

Kissell, R.J., Jr. 1996. Competitive interactions among bighorn sheep, feral horses, and mule deer in Bighorn Canyon National Recreation Area and Pryor Mountain Wild Horse Range. Ph.D. Diss. Montana State Univ., Bozeman, Mont.

Knapp, A.K., and T.R. Seastedt. 1986. Detritus accumulation limits productivity of tallgrass prairie. BioSci. 36:662-668.

Lauenroth, W.K. 1979. Grassland primary production: North American grasslands in perspective. p. 3-24. In: N.R. French (ed.), Perspectives in grassland ecology. Springer-Verlag, New York, N.Y.

McNaughton, S.J. 1979. Grazing as an optimization process: grass-ungulate relationships in the Serengeti. Amer. Nat. 113:691-703.

McNaughton, S.J. 1985. Ecology of a grazing ecosystem: the Serengeti. Ecol. Mono. 55:259-294.

McNaughton, S.J., L.L. Wallace, and M.B. Coughenour. 1983. Plant adaptation in an ecosystem context: effects of defoliation, nitrogen, and water on growth of an African $\mathrm{C}_{4}$ sedge. Ecol. 64:307-318.

Milchunas, D.G., J.R. Forwood, and W.K. Lauenroth. 1994. Forage production across fifty years of grazing intensity treatments in the shortgrass steppe. J. Range Manage. 47:133-139.

Pandey, C.B. and J.S. Singh. 1992. Rainfall and grazing effects on net primary productivity in a tropical savanna, India. Ecol. 73:2007-2021.

Peterson, J., J.T. Fahnestock, and J.K. Detling. 1997. Ungulate/vegetation interactions at the Pryor Mountain Wild Horse Range. Final report to the National Park Service.

Polley, H.W. and J.K. Detling. 1988. Herbivory tolerance of Agropyron smithii populations with different grazing histories. Oecologia 77:261-267.

Richards, J.H., R.J. Mueller, and J.J. Mott. 1988. Tillering in tussock grasses in relation to defoliation and apical bud removal. Ann. Bot. 62:173-179.

Risser, P.G. 1969. Competitive relationships among herbaceous grassland plants. Bot. Rev. 35:251-284.

Ruess, R.W., S.J. McNaughton, and M.B. Coughenour. 1983. The effects of clipping, nitrogen source and nitrogen concentration on the growth responses and nitrogen uptake of an East African sedge. Oecologia 59:253-261.
Sala, O.E. and W.K. Lauenroth. 1982. Small rainfall events: an ecological role in semiarid regions. Oecologia 53:301-304.

Sala, O.E., W.J. Parton, L.A. Joyce, and W.K. Lauenroth. 1988. Primary production of the central grassland region of the United States. Ecol. 69:40-45.

SAS Institute. 1989. SAS/STAT User's Guide, Fourth Edition. SAS Institute Inc., Cary, N.C.

Schwartz, C.C. and J.E. Ellis. 1981. Feeding ecology and niche separation in some native and domestic ungulates on the shortgrass prairie. J. Appl. Ecol. 18:343-353.

Seastedt, T.R. 1985. Maximization of primary and secondary productivity by grazers. Amer. Nat. 126:559-564.

Simoes, M. and Z. Baruch. 1991. Responses to simulated herbivory and water stress in two tropical $\mathrm{C}_{4}$ grasses. Oecologia 88:173-180.

Toft, N.L., S.J. McNaughton, and N.J. Georgiadis. 1987. Effects of water stress and simulated grazing on leaf elongation and water relations of an East African grass, Eustachys paspaloides. Australian J. Plant Phys. 14:211-226.

Vinton, M.A., D.C. Hartnett, E.J. Finck, and J.M. Briggs. 1993. Interactive effects of fire, bison (Bison bison) grazing and plant community production in tallgrass prairie. Amer. Midl. Nat. 129:10-18.

Wallace, L.L., S.J. McNaughton, and M.B. Coughenour. 1984. Compensatory photosynthetic responses of three African graminoids to different fertilization, watering and clipping regimes. Bot. Gaz. 145:151-156.

Weaver, T. 1985. Summer showers: their sizes and interception by surface soils. Amer. Midl. Nat. 114:409-413.

Williams, C.S. 1963. Ecology of bluebunch wheatgrass in northwestern Wyoming. Ph.D. Diss., Univ. of Wyoming, Laramie, Wyo.

Zhang, J. and J.T. Romo. 1995. Impacts of defoliation on tiller production and survival of northern wheatgrass. J. Range Manage. 48:115-120. 